\title{
VEGETATION AND LANDSCAPE DIFFERENTIATION OF THE TERRITORY OF GOLD DEPOSIT AND IT'S ENVIRONMENT (Republic of Sakha, Yakutia, Russia)
}

\author{
Alexander Sizykh ${ }^{1 *}$, Ruslan Moritz ${ }^{1}$, Mikhail Pastukhov ${ }^{2}$, Vera Poletaeva ${ }^{2}$ \\ I*Siberian Institute of Plant Physiology and Biochemistry SB RAS, 664033, Irkutsk, Russia; \\ ${ }^{2}$ A.P. Vinogradov Institute of Geochemistry SB RAS, 664033, Irkutsk, Russia; \\ *Corresponding Author Alexander Sizykh, e-mail: alexander.sizykh@gmail.com;
}

Received February 2021; Accepted March 2021; Published April 2021;

DOI: https://doi.org/10.31407/ijees11.220

\begin{abstract}
The analysis of scientific publications available in open press, reports and data of nature studies with herbaria sampling at the territory adjacent to the enterprise allowed to reveal main parameters of vegetation structure, species composition of phytocoenoses and landscapes facial composition involved directly into economic activities within the above mentioned territory. The structural-dynamics peculiarities of the plant communities and landscapes differentiation of the research region were been observing. For the territory the tableland-mountain peak, mountainslope and mountain-valley types of the localities are characteristics. The landscapes here were occurred by mountain-tundra, sub-golets, mountain-open woodland, mountain-taiga of the nature-territorial complexes and maries too. Plateau-near-peak type of the site is formed with mountain-tundra natural territorial associations dominated by goltsy-stony landscapes groups in the upper parts of steep slopes; mountain-slope site type is formed by sub-goltsy and mountain-woodland natural territorial associations with dominance of moderately steep slopes with mountain pine and lichens, larch woodlands at lower parts of gentle slopes and green mosses larch forests with mountain pine in a group of landscapes; mountain-valley site type is characterized by mountain-taiga, mountainwoodland and marshy natural territorial associations with dominance of near-valley cowberry - green mosses and near-valley larch and spruce-larch woodlands as well as of mossy dwarf birches and swampy sedge meadows in a group of landscapes. The obtained materials on phytocoenoses composition and landscape differentiation may serve as a basic information while assessing where and in which way the environment changes under the conditions of direct technogenic impact in space and time. The studies, which are mainly reconnaissance, allowed us to reveal a rather complicated structural-territorial organization of phytocoenoses and landscape differentiation of the territory.
\end{abstract}

Key words: vegetation, structure of landscapes, natural complex, Republic Sakha (Yakutyia) 